\title{
MODELLING THE DETERMINANTS OF FESTIVAL VISITORS' BEHAVIOURAL INTENTIONS
}

\section{Jaroslav Ďad'o', Vanda Maráková2, Janka Táborecká-Petrovičová3, Tamara Rajić ${ }^{4}$}

\footnotetext{
1 Matej Bel University, Faculty of Economics, Department of Corporate Economics and Management, Slovakia, ORCID: 0000-0001-9396-8499, jaroslav.dado@umb.sk;

2 Matej Bel University, Faculty of Economics, Department of Tourism and Hospitality, Slovakia, ORCID: 0000-00021148-8393, vanda.marakova@umb.sk;

3 Matej Bel University, Faculty of Economics, Department of Corporate Economics and Management, Slovakia, ORCID: 0000-0003-4351-782X, janka.taborecka@umb.sk;

4 Economics Institute a.d. Belgrade, Serbia, ORCID: 0000-0002-2797-584X, tamara27rajic@gmail.com.
}

\begin{abstract}
Limited efforts have been made to date to examine the determinants of visitors' behavioural intentions in the context of cultural festivals in Central Europe. The present study aims to fill this void in literature by proposing a conceptual model incorporating the festival setting that has thus far scantly examined perspective of the fulfilment of motives and a subjective well-being as a consequence of a festival experience. The application of structural equation modelling (SEM) on a sample of 770 festival visitors in Slovakia provided support for the concept of visitors' motivation as a higher-order construct and its direct relatedness to perceived value of a festival experience and visitors' satisfaction. Both satisfaction and visitors' subjective well-being emerged as direct antecedents to visitors' behavioural intentions and mediators of the impact of perceived value on visitors' behavioural intentions. Implications of the study are provided and limitations and directions for future research are highlighted.
\end{abstract}

Keywords: Motivation, perceived value, satisfaction, subjective well-being, behavioural intentions, cultural festival.

JEL Classification: C51, D91, M39, R32.

APA Style Citation: Ďad’o, J., Maráková, V., Táborecká-Petrovičová, J., \& Rajić, T. (2020). Modelling the Determinants of Festival Visitors' Behavioural Intentions. E\&M Economics and Management, 23(2), 173-190. https://doi.org/10.15240/tul/001/2020-2-012

\section{Introduction}

Over the previous two decades, festivals have gained a prominent position within the world's tourism and leisure industry. Festivals are regarded as an effective strategy for the promotion of the tourism industry and the local economy. Hosting a festival may attract tourists who otherwise would not choose to visit the destination and whose expenditures contribute to income and tax revenues in host communities (Getz \& Page, 2016). Festivals and events facilitate the positioning of a locality as a tourism destination (Hudson et al., 2015) and can be effective tools in combating the seasonality of tourism demand (Tkaczynski \& Rundle-Thiele, 2011; Yolal et al., 2016). Festivals play an important role in preserving cultural heritage and reinforce residents' pride of being members of host community (Yolal et al., 2016; Yoon, Lee, \& Lee, 2010). Due to a number of benefits brought by hosting festivals, significant attention has been paid to festival studies over previous years.

The vast majority of previous studies focused on the importance of visitors' motives, dimensions of motivation and differences in 
the importance of motivational domains based on visitors' socio-demographic characteristics, previous visitations, types of event being studied, etc. (Crompton \& McKay, 1997; Kang et al., 2014; Lee, 2000). Sparse attempts have been made to date to incorporate visitors' perceptions of the fulfillment of motives into an integrative framework explaining the formation of post-visitation intentions. In addition, no previous attempt has been made to examine the viability of visitors' motivation as a higher-order construct and its impact on visitors' evaluative judgements of a festival experience, such as perceived value of the experience and satisfaction. Understanding of what makes festival visitors satisfied and eager to spread positive word-of-mouth about an event is of particular importance nowadays, in the era of social networking and social media communication, when posts of satisfied visitors may reach a wide audience and exert significant influence on prospective visitors' decisionmaking (Dabija et al., 2018; Hruška \& Pásková, 2018). Beneficial effects of satisfied festival visitors may be reaped by festival organizers and local communities hosting a festival, as well, as online recommendations may attract new visitors and contribute to festival sustainability and add to the attractiveness and competitive standing of the local community hosting a festival as a tourism destination (Maráková et al., 2016).

Festivals provide a number of opportunities for visitors to entertain themselves, socialize, experience something different from everyday life and meet various psychological needs. It is therefore likely that festival attendance will positively affect visitors' subjective wellbeing and stimulate future festival visitations. Whereas several empirical works have examined the behavioural consequences of festival evaluation (Kim, Kim, \& Goh, 2011; Lee at al., 2008; Lee, 2016; Wu, Wong, \& Cheng, 2014; Yoon, Lee, \& Lee, 2010), limited attention has been paid to understanding visitors' wellbeing as a consequence of festival experience and its impact on post-visitation intentions.

Although the European continent has been recognized as a particularly fruitful festival venue, due to rising number and diversity of festivals on the continent (Newbold et al., 2015), surprisingly little research has been undertaken on the continent with the aim of explaining the visitors' decision-making process. As to the best of our knowledge, no previous research has examined the influential factors of festival visitors' future intentions in the context of traditional cultural festivals in Central Europe.

Therefore, this present study aims to fill these voids in literature by proposing a conceptual framework which integrates visitors' motivation as a higher-order construct, perceived value of a festival experience, satisfaction and visitors' well-being as a consequence of attending a festival, their interrelationships and the impact on visitors' behavioural intentions. The Enhanced understanding of the determinants is likely to provide directions for festival organizers with regards to how to tailor festival offerings to contribute to visitors' positive perceptions of a festival and enhance their future visitations. In accordance with the vast research on visitors' motivation across festival/national/ cultural contexts which resulted in broadly similar, yet distinct dimensions of motivation, this study sets out to examine the domains of visitors' motivation in the context of traditional cultural festivals taking place in Central Europe. Subsequently, the viability of motivation as a higher-order construct is examined, followed by the examination of structural relationships between the constructs.

\section{Conceptual Background and Hypotheses}

\subsection{Motivation to Attend Festivals}

Understanding visitors' motivation is a key prerequisite for better planning and marketing of festivals and tailoring festival activities to the needs of target visitor segments. Motivation can be defined as "psychological/biological need and wants that arouse, direct, and integrate a person's behaviour" (Park, Reisinger, \& Kang, 2008, p. 161). Although some studies have indicated the distinction between tourists' motives and motivation, defining motives as generic energizers for behaviour and motivation as situation-specific and object-directed behaviour (Gnoth, 1997), this paper will use the terms interchangeably. Research on festival visitors' motivation has generally been based upon the theory of push and pull motivators and escapeseeking dichotomy, which imply that festival visitors' behaviour is directed by both extrinsic and intrinsic, personal and interpersonal, motivators (Crompton \& McKay, 1997).

The vast majority of previous studies focused on the examination of the domains of motivation. 
In one of the earliest studies on festival visitors' motivation Mohr et al. (1993) in the context of an air balloon festival in South Carolina identified five domains of motivation: socialization, family togetherness, excitement, escape and event novelty. Crompton and McKay's (1997) study of Fiesta San Antonio visitors' motivation yielded six-dimensional construct of motivation, consisting of cultural exploration, novelty, recover equilibrium, known-group socialization, external interaction, gregariousness. Factor analysis of 32 motivational items in the context of Kyongju World Cultural Expo in South Korea yielded the following seven dimensions of visitors' motivation: cultural exploration, family togetherness, escape, novelty, external group socialization, event attractions, known group socialization (Lee, 2000). Five dimensions emerged from the study on visitors' motivation in the context of the International festival of environmental film and video in Brazil, i.e. family togetherness, socialization, site attraction, festival attraction and escape from the normal routine (Kim, Borges, \& Chon, 2006). A study on visitors' motivation in the context of the 2005 Naadam Festival in Ulaanbaatar yielded five dimensions of motivation, cultural exploration, togetherness, socialization, sports attraction, local special events (Schofield \& Thompson, 2007). Park, Reisinger and Kang (2008) in the context of the South Beach Wine and Food Festival in Florida provided evidence in support of seven dimensions of visitors' motivation, such as taste, enjoyment, social status, change, meeting people, family, meeting experts.

Review of previous research indicates that broadly similar motivational domains emerged from different festival, national and cultural settings. However, studies have frequently yielded different groupings of items and indicated the relevance of context specific motives (Schofield \& Thompson, 2007). Whereas the majority of previous studies have focused on the importance of motivational factors (Mohr et al., 1993; Park, Reisinger, \& Kang, 2008), this study has centred on visitors' perceptions of the fulfilment of motives and its impact on attendees' post-visitation evaluation of recently visited cultural event.

While it is intuitively plausible that the fulfilment of visitors' motives should be positively related to perceived value of a festival experience, little empirical research has been conducted to examine the link between these two constructs. However, previous leisure and travel studies have provided evidence of positive impact of motivation and the domains of motivation on travelers' value perceptions (Lo \& Lee, 2011; Prebensen, Woo, \& Uysal, 2014). Several attempts have been made to study the impact of motivation on satisfaction in a festival setting. Lee and Beeler (2009) in the context of the $19^{\text {th }}$ Annual Winter Festival in Florida provided evidence of significant impact of reminiscence, a dimension of visitors' motivation, on their satisfaction with the attendance of the event. Lee and Hsu's (2013) study in the context of two aboriginal festivals taking place in Taiwan indicated significant direct impact of visitors' motivation on satisfaction with the events. Local special events and cultural exploration, as the domains of visitors' motivation, emerged as significant determinants of overall visitor satisfaction in the context of a traditional cultural and sporting festival, Naadam festival, held in Ulaanbaatar, Mongolia (Schofield \& Thompson, 2007). Based on the above arguments the following hypotheses are proposed:

H1: Visitors' motivation is positively related to perceived value of a festival experience.

H2: Visitors' motivation is positively related to satisfaction.

\subsection{Perceived Value of a Festival Experience}

The construct of perceived value has attracted significant research attention over previous three decades. Recent tourism and hospitality studies have identified perceived value as one of principal determinants of customer satisfaction (Kim, Woo, \& Uysal, 2015; Lee, Yoon, \& Lee, 2007) and a major driver of customer behavioural intentions (Dedeoglu et al., 2018; Lee, Yoon, \& Lee, 2007). In spite of extensive examinations of perceived value, consensus as to the best way to measure the construct has not been reached yet. Literature review indicates numerous concepts of perceived value. Previous studies in tourism and hospitality have differentiated between hedonic and utilitarian value, functional, emotional, social value, value for money, novelty value, quality value, economic and knowledge value (Jo, Lee, \& Reisinger, 2014; Lee, Yoon, \& Lee, 2007; Prebensen \& Xie, 2017). The most widely accepted concept of perceived value was proposed by Zeithaml (1988), who explained the construct as a trade-off between the benefits 
a customer gets from a product or a service and a sacrifice, i.e. monetary and non-monetary costs that he has to make in order to obtain the benefits. This concept provided the foundation for the measurement of perceived value in the majority of later studies, and has been adopted in this study, as well.

Consumption of experiential content, such as tourism experiences, implies that consumers actively participate in the value co-creation process and their psychological involvement in creating value of the experience results in satisfaction (Prebensen \& Xie, 2017). Yoon, Lee and Lee (2010) provided evidence of significant impact of festival value on visitors' satisfaction in the context of the Punggi Ginseng festival in South Korea. The antecedent role of perceived value to visitors' satisfaction has also been supported in the context of a food event in the United States (Kim, Kim, \& Goh, 2011). Sung et al.'s (2016) study in the context of the Amis Harvest Festival indicated significant impact of perceived value of the festival on visitor satisfaction with Hualien, tourist destination which hosted the event. Several studies have supported significant impact of festival value on visitors' behavioural intentions. In the context of cultural Punggi Ginseng festival, value emerged as a significant direct determinant of both first-time and repeat visitors' willingness to recommend and revisit the festival, whereas perceived value emerged as a more significant determinant of visitors' behavioural intentions for repeat visitors (Lee et al., 2009). Perceived value was also found to significantly influence attendees' intention to revisit a food festival in the USA (Kim et al., 2011). Several empirical studies have also highlighted that attendees' intentions to revisit a festival can be increased by increasing perceived value of the event (Akhoondnejad, 2016; Kim, Kim, \& Goh, 2011; Lee, Lee, \& Yoon, 2009). Previous findings lead to the following hypotheses:

H3: Perceived value of a festival experience is positively related to visitors' satisfaction.

H4: Perceived value of a festival experience is positively related to visitors' behavioural intentions.

\subsection{Visitors' Satisfaction and Behavioural Intentions}

Customer satisfaction has been long praised by scholars and practitioners alike for its influence on customers' willingness to buy additional goods and services from the company and spread positive word-of-mouth communication (Han \& Hyun, 2018). Customers' willingness to recommend an event is regarded as the best indicator or their true loyalty (Reichheld, 2003), which according to Oliver (1999) is reflected in a customer's commitment to re-buy a product or a service from a preferred vendor, in spite of competitors' marketing efforts and situational factors which may provide incentives for a customer to switch. Oliver (1999) delineates four phases of loyalty development, cognitive, affective, conative and action loyalty. As the measurement of action loyalty would require purchase history, it is difficult to measure this construct in practice. Therefore, examinations of customer loyalty have mainly focused on conative, i.e. behavioural intention, loyalty, which is manifested in a customer's desire to repurchase. Given the number of positive socio-economic implications of festivals, and at the other side the competitiveness of festival market, the delivery of satisfactory festival experience is a necessary prerequisite to stimulate attendees' revisit intentions and referrals and therewith promote festival's sustainability.

Several studies have examined the impact of satisfaction on festival visitors' behavioural intentions. In the context of spring music festivals in Southern Taiwan, Lee (2016) provided support for the positive impact of visitors' satisfaction on willingness to recommend the festival, spread positive word-of-mouth and revisit the festival. Kim et al.'s (2011) study in the context of a culinary festival in the USA indicated significant impact of visitors' satisfaction on their intentions to revisit the festival. Results of a study performed in a context of food and wine festival in Italy revealed significant impact of visitors' satisfaction on their willingness to spread positive word-of-mouth and revisit the festival (Mason \& Paggiaro, 2012). Positive effects of visitor satisfaction on their referral intentions and willingness to revisit the festival have been also supported in a context of Macau food festival in China (Wu, Wong, \& Cheng, 2014). Positive impact of visitors' satisfaction on behavioural intentions has also been supported in the context of international Andong Mask Dance festival in South Korea (Lee at al., 2008), Punggi Ginseng festival in South Korea (Yoon, Lee, \& Lee, 2010), Gwangju Kimchi local food festival in South Korea (Kim, Suh, 
\& Eves, 2010) and handicrafts festival in Iran (Akhoondnejad, 2016). Therefore, the following hypothesis is formulated:

H5: Visitors' satisfaction is positively related to behavioural intentions.

\subsection{Visitors' Subjective Well-being}

Subjective well-being of customers has gained prominence in recent tourism and hospitality research. In a festival setting Yolal et al. (2016) define subjective well-being as a cognitive and affective evaluation of an event, whereas cognitive evaluation refers to an assessment of the contribution of a festival experience to a person's life satisfaction and affective evaluation is based on the assessment of feelings and emotions a festival evokes. Subjective well-being plays an essential role in an individual's life as it contributes to the optimal functioning capacity of a person and its confidence of being capable of fulfilling important life goals and coping with the everyday demands of life. As such, it has been recognized as an overarching goal of contemporary societies and the phenomenon which can be employed by leisure and tourism businesses to impact a customer's decisionmaking process (Pyke et al., 2016).

Review of literature indicates that subjective well-being has been considered interchangeably with life satisfaction, perceived quality of life, hedonic well-being, happiness (Kim, Woo, \& Uysal, 2015; Uysal et al., 2016). Previous studies indicate that positive feelings invoked by tourism experiences contribute to a person's life satisfaction both directly and indirectly, through the enhancement of leisure well-being and the augmentation of well-being related to the non-leisure life domains, such as social life, cultural life, spiritual life, family life (Sirgy, 2010; Uysal et al., 2016). Some empirical findings indicate that participation in tourism activities has an immediate, yet temporary effect on occasion-specific well-being of tourists, without an effect on chronic subjective wellbeing after the vacation (Chen, Lehto, \& Cai, 2013). Interestingly, Chen et al.'s (2013) study indicated that subjective well-being of a control group, which did not take vacations during the experiment period, slightly increased, which the authors ascribed to respondents' participation in a number of festivals taking place during the experiment period. Several studies in tourism and hospitality settings provided support for the positive impact of satisfaction with the experience on subjective well-being of customers (Kim, Woo, \& Uysal, 2015; Meng \& Choi, 2017). Su, Swanson and Chen's (2016) study in the context of hospitality services indicates significant impact of overall tourists' satisfaction on subjective well-being. While their findings further indicate the mediating role of customer satisfaction in the relationship between the cognitive construct of service quality and subjective well-being, the present study postulates that customer satisfaction will partially mediate the relationship between the cognitive construct of perceived value of a festival experience and subjective wellbeing, and that positive perceptions of time, finance, energy and effort spent during festival visitation will also directly contribute to visitors' perceptions of well-being as a consequence of attending a festival. In line with Kim, Woo and Uysal's (2015) evidence of positive impact of elderly tourists' overall quality of life on revisit intentions, the present study also postulates that the perception of festival attendance as an enriching experience will have a positive effect on visitors' intentions to revisit the festival and share their positive experiences with others. Based on the above arguments, the following hypotheses are proposed:

H6: Perceived value of a festival experience is positively related to visitors' subjective wellbeing.

H7: Visitors' satisfaction is positively related to visitors' well-being.

H8: Visitors' well-being is positively related to behavioural intentions.

A conceptual model which integrates hypothesized relationships is presented in Fig. 1.

\section{Study Context and Methodology 2.1 Study Context}

The study has been performed in the administrative region of Banska Bystrica, the largest region of Slovakia, which is located in the centre of the country. Several cultural festivals (events) traditionally take place in the region of Banska Bystrica in November and December, when data collection was performed, such as Katarinsky jarmok in Zavadka nad Hronom, Ondrejsky jarmok in Brezno and The visitation of St. Nicholas, which is celebrated in every district of the region of Banska Bystrica and all over the country during December. These festivals are 


\section{Fig. 1: Model of the determinants of festival visitors' behavioural intentions}

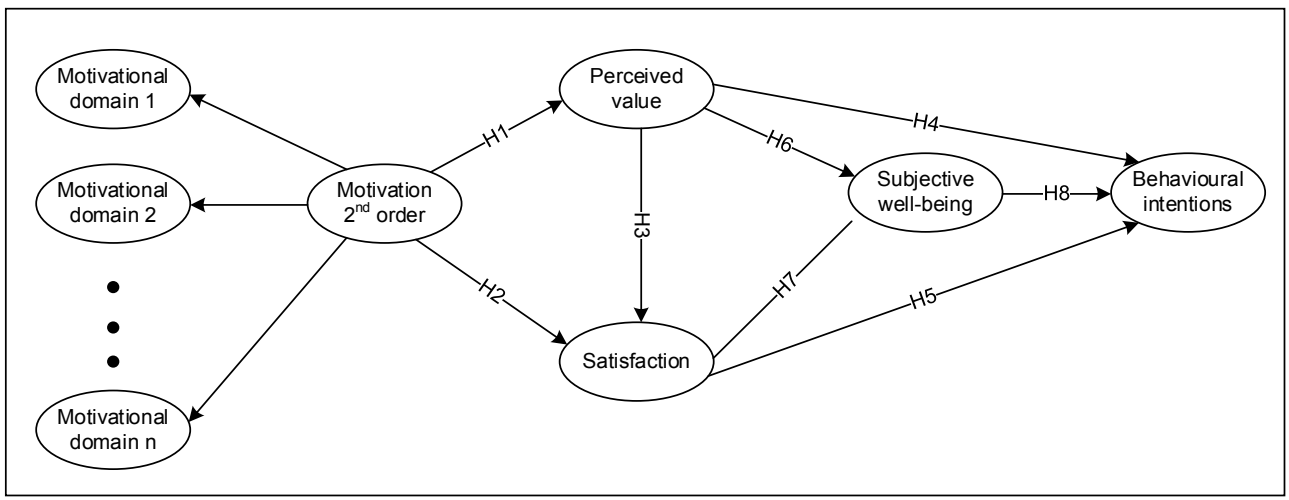

Source: own

regarded as unique opportunities to preserve local handicrafts, customs and tradition for the generations to come and to position a festival and the locality where it takes place as an attractive product and tourism destination. Festivals are held on open-air venues which are equipped with stands displaying and selling local delicacies, traditional sweets and a variety of hand-made goods. The atmosphere is enriched by the offer of homemade pork and cheese specialties and traditional cuisine. In addition, visitors are amused by various folklore performances. Special attention is usually paid to programme and activities for the entertainment of children. Some of these public celebrations have a tradition several centuries long, such as Bartolomejsky jarmok held in llava, which dates back to the 15th century, and Bardejovsky jarmok, which celebrated its 666th anniversary in 2018. "The fair of all fairs" is the epithet popularly attached to Radvansky jarmok in Slovakia, hosted by Banska Bystrica, whose long tradition dates back to 1655 , when Radvan village in the region of Banska Bystrica was awarded the privilege to organize a market on the day of birth of Virgin Mary (slovakia.travel/en).

\subsection{Sample Design and Data Collection}

The study was performed on a convenience sample of Slovak festival visitors. Students attending Marketing and Tourism-related courses participated in data collection, as interviewers. Due to harsh weather conditions in Slovakia at the end of November, when data collection was about to start, it was deemed inappropriate to conduct interviews at a festival venue, as traditional festivals are held in public area and open-air venues. Rather, students were instructed to approach respondents at locations which were more convenient for questionnaire fulfilment, such as shopping mall area, local libraries, cafes and restaurants. Data collection was performed by means of paper-based structured questionnaire. Students outlined the aim of the research and invited respondents to participate in the study. At the beginning of field research, several near-by communities hosted local cultural festivals. Students coming from these communities interviewed local residents who visited the event, whereas other participants in the sample were instructed by interviewers to respond referring to their most recent festival attendance. Nine hundred questionnaires were distributed during data collection, of which 770 complete questionnaires were deemed usable and included in data analysis, whereas 130 questionnaires which were partially completed as a result of respondents' dropping-out during the interviews or those questionnaires which indicated an obvious acquiescence responding, were excluded from further consideration. Field research yielded a response rate of $85.5 \%$. The high response rate was a result of respondents' eagerness to express their opinions about a phenomenon 
which they regard as socially important. As at the beginning of field research, no official statistics related to the profile of visitors of traditional cultural festivals in Slovakia was available. Students who participated in the study as interviewers were given quotas to follow during the selection of respondents, in terms of gender and age of respondents, which in total on a sample of 900 respondents were supposed to resemble the demographic profile of the population in Slovakia. In addition, students were also permitted to make some deviations in recruiting respondents, in terms of age and gender defined by their respective quotas, which finally yielded a convenience sample. Quotas based on demographic profile of Slovak population were chosen due to unavailability of official statistics related to the profile of traditional cultural festival visitors in Slovakia and as traditional cultural festivals in Slovakia are generally visited by people of both genders and all age groups. Profile of festival visitors who participated in the study is presented in the results section.

\subsection{Questionnaire Design}

Questionnaire items were proposed on the basis of literature review, followed by individual interviews and group discussions with experts in marketing and tourism and visitors of traditional cultural events. Forty-five items matching the constructs of the proposed model resulted from secondary and primary qualitative research. The items used to measure visitors' motivation were adapted from previous studies (Crompton \& McKay, 1997; Lee, 2000; Lee \& Hsu, 2013; Mohr et al., 1993; Nicholson \& Pearce, 2001; Park, Reisinger, \& Kang, 2008). The perceived value of a festival experience was operationalized with 4 items adapted from previous research (Kim, Woo, \& Uysal, 2015). Three items, adapted from the literature (Lee, 2016; Mason \& Paggiaro, 2012; Yoon, Lee, \& Lee, 2010) were used to measure the construct of visitors' satisfaction. Subjective well-being was measured with three items adapted from Yolal et al. (2016). Finally, the construct of visitors' behavioural intentions was operationalized using three items derived from the literature (Lee, 2016; Lee et al., 2008; Mason \& Paggiaro, 2012). Two additional items were added to the scale measuring behavioural intentions - Visitors' willingness to recommend festival attendance to people from other regions of Slovakia and willingness to encourage foreigners to visit the festival in Slovakia.

Items related to the constructs of the study were measured on a 7-point Likert-type scale, ranging from (1) completely disagree to (7) completely agree, whereas respondent information was measured by a categorical scale. The initial questionnaire was developed in English, translated into Slovak language and back-translated, in order to ensure that the essential meaning of items, which were taken from previous studies and which had been originally developed in English, and translated into Slovak language for the purpose of this study, was preserved. Prior to its largescale administration, the survey instrument was revised based on feedback from festival visitors and marketing and tourism scholars and professionals, which assured content validity of the measurement instrument.

\subsection{Data Analysis}

Hypothesized relationships have been examined with a sample of 770 festival visitors, by means of structural equation modelling, following Anderson and Gerbing's (1988) twostep modelling approach, which implies the examination of measurement model, followed by the examination of structural relationships. Descriptive statistics of questionnaire items indicated moderate deviation from normal distribution, as all skewness and kurtosis values were in the acceptable \pm 1 range, or not far out of the range, as presented in the Appendix A. Due to the presence of both positive and negative values, Robust maximum likelihood has been applied as a method of parameter estimation, using covariance matrix as an input for the analyses.

The underlying dimensionality of visitors' motivation has been examined by means of exploratory factor analysis (EFA), on a dataset containing 278 observations. Validity and reliability of resulting dimensions of motivation have been assessed by means of confirmatory factor analysis (CFA), on a sample of 492 observations. Second-order confirmatory factor analysis of visitors' motivation has been performed on a sample of 770 observations, followed by the examination of validity and reliability of perceived value, satisfaction, subjective well-being and visitors' behavioural intentions. Data analyses have been performed using SPSS v.17 and LISREL 8.80 . 


\section{Empirical Results}

\subsection{Profile of Respondents}

Considerably more female $(n=475 ; 61.7 \%)$ than male respondents $(n=295 ; 38.3 \%)$ participated in the study. Most respondents (26.9\%) were between 20-29 years of age, followed by respondents between 40-49 (16.2\%), 30-39 $(15.8 \%), 60$ years and older respondents (15.5\%), respondents in the age group 50-59 (14.4\%) and respondents between 15 and 19 years of age $(11.2 \%)$. Slightly more respondents with secondary education participated in the study $(45.8 \%)$, in comparison to respondents with university degrees $(43.4 \%)$ and primary education $(10.8 \%)$. In terms of frequency of visiting traditional cultural festivals, almost equal number of respondents reported visiting them once per year (35.5\%) and 2-3 times per year $(35.2 \%)$, whereas $14.8 \%$ of respondents reported attending traditional cultural festivals at least three times per year. The majority of respondents reported visiting recent traditional cultural festival with both friends and family members $(42.1 \%)$. During their last visitation, the majority of respondents were accompanied by $3-4$ persons $(40.4 \%), 31.4 \%$ of respondents reported being accompanied by five and more people, whereas $25.6 \%$ of respondents reported attending recent traditional cultural festival in groups of 2-3 persons.

\subsection{Domains of Visitors' Motivation}

Dimensionality of the construct of visitors' motivation has been examined by means of a principal component analysis (PCA), with promax rotation. Prior to the extraction of factors, Kaiser-Meyer-Olkin measure of sampling adequacy of 0.860 and the significance of Bartlett's test of sphericity $\left(X^{2}{ }_{(435)}=3,243.319\right.$, $p<.001)$ indicated appropriateness of the sample for the application of factor analysis (Hair et al., 2010). As 30 motivation items were entered into factor analysis, which was performed on a sample of 278 observations, a requirement of having at least five times as many observations as number of items to be analyzed was satisfied (Hair et al., 2010). Factor loadings less than 0.40 were suppressed and Kaiser's criterion of extracting factors based on eigenvalues greater than 1 was applied. Iterative procedure based on the examinations of cross-loading of the items and reliabilities of groups of items loading on the same factor yielded six-dimensional structure of visitors' motivation. Out of 30 items entered into factor analysis, 17 items were retained for further analyses. The reliability of resulting factors was examined and coefficients ranging from 0.755 to 0.851 , being higher than the lower threshold of 0.70 , were deemed acceptable. The resulting factors were named as follows: F1 - new and different things, F2 - reconnection with culture and traditions, F3 - family togetherness, F4 - reducing tension, F5 - support for local community, F6 - being with people with similar interests. Factor loadings, eigenvalues and variance explained prior to promax rotation are presented in Tab. 1. These six factors, which explained $69.2 \%$ of the total variance, were subjected to confirmatory factor analysis in the following stage of data analysis.

\subsection{Analyses of Measurement Models}

First, the overall fit of the first-order measurement model of visitors' motivation was assessed, followed by the examination of the measurement model of visitors' motivation as a second-order construct. Finally, validity of perceived value, satisfaction, subjective well-being and visitors' behavioural intentions was assessed on a dataset including 770 observations.

Six-dimensional model of visitors' motivation was assessed on the basis of several fit indices, such as Satorra-Bentler normed chi-square, goodness of fit index (GFI), root mean square error of approximation (RMSEA), standardized root mean square residual (SRMR), normed and non-normed fit index (NFI, NNFI), comparative fit index (CFI). Values of GFI, NFI, NNFI, CFI range from zero to 1.00 , whereas values higher than 0.90 and close to 1.00 indicate a good fit of the model (Hair et al., 2010). The SRMR values range between 0 and 1.00 and values up to 0.08 are indicative of good-fitting models (Tabachnick \& Fidell, 2007). A good fit of the model to the sample data is also indicated by the value of RMSEA close to zero and up to 0.08 (Hair et al., 2010).

The ratio of the $X^{2}$ to the degrees of freedom, i.e. normed chi-square, which was lower than 3 indicated acceptable model fit (Hair et al., 2010). A good-fitting model was also indicated by other fit indices, as presented in Tab. 1. Evidence in support of reliability of the dimensions of motivation was provided by reliability coefficients exceeding the minimum standard of 0.70 (Hair et al., 2010). 


\begin{tabular}{|c|c|c|c|c|c|c|c|}
\hline \multicolumn{3}{|c|}{ Items } & $\begin{array}{c}\text { EFA } \\
(n=278)\end{array}$ & $\begin{array}{c}\text { Com- } \\
\text { munalities }\end{array}$ & Reliability $^{1}$ & $\begin{array}{c}1^{\text {st }} \text {-order } \\
\text { CFA } \\
(n=492)\end{array}$ & t-value \\
\hline \multicolumn{3}{|c|}{$\begin{array}{l}\text { Factor 1: New and different things } \\
\text { Eigenvalue }=5.563 ; \% \text { of Variance }=30.904\end{array}$} & & & .790 & & \\
\hline \multicolumn{3}{|l|}{ To experience new things } & .811 & .585 & & 0.64 & 14.87 \\
\hline \multicolumn{3}{|l|}{ To satisfy curiosity } & .779 & .558 & & 0.54 & 12.98 \\
\hline \multicolumn{3}{|c|}{ To experience something stimulating and exciting } & .720 & .553 & & 0.65 & 16.25 \\
\hline \multicolumn{3}{|c|}{ Festival provided a variety of things to see and do } & .595 & .587 & & 0.74 & 19.48 \\
\hline \multicolumn{3}{|c|}{ To experience different things } & .624 & .589 & & 0.78 & 20.96 \\
\hline \multicolumn{3}{|c|}{ To experience a unique event } & .541 & .519 & & 0.65 & 15.96 \\
\hline \multicolumn{3}{|c|}{$\begin{array}{l}\text { Factor 2: Reconnection with culture }+ \text { traditions } \\
\text { Eigenvalue }=1.851 ; \% \text { of Variance }=10.284\end{array}$} & & & .851 & & \\
\hline \multicolumn{3}{|c|}{ To reconnect with local customs and tradition } & .868 & .819 & & 0.85 & 20.69 \\
\hline \multicolumn{3}{|c|}{ To reconnect with local culture } & .861 & .825 & & 0.90 & 24.73 \\
\hline \multicolumn{3}{|c|}{ To enjoy traditional food and handicrafts } & .735 & .611 & & 0.60 & 12.26 \\
\hline \multicolumn{3}{|c|}{$\begin{array}{l}\text { Factor 3: Family togetherness } \\
\text { Eigenvalue }=1.509 ; \% \text { of Variance }=8.383\end{array}$} & & & .803 & & \\
\hline \multicolumn{3}{|c|}{$\begin{array}{l}\text { Festival provided an opportunity for entire family to } \\
\text { enjoy it }\end{array}$} & .863 & .759 & & 0.83 & 14.69 \\
\hline \multicolumn{3}{|c|}{$\begin{array}{l}\text { Festival provided an opportunity for all family } \\
\text { members to do something together }\end{array}$} & .892 & .769 & & 0.73 & 14.52 \\
\hline \multicolumn{3}{|c|}{$\begin{array}{l}\text { Factor 4: } \text { Reducing tension } \\
\text { Eigenvalue = } 1.282 ; \% \text { of Variance }=7.122\end{array}$} & & & .776 & & \\
\hline \multicolumn{3}{|c|}{$\begin{array}{l}\text { Visiting festival provided an opportunity to reduce } \\
\text { built-up tension, anxieties and frustrations }\end{array}$} & .917 & .822 & & 0.78 & 17.71 \\
\hline \multicolumn{3}{|c|}{$\begin{array}{l}\text { Visiting festival provided an opportunity to recover } \\
\text { from my usually hectic pace of life }\end{array}$} & .867 & .804 & & 0.78 & 17.98 \\
\hline \multicolumn{3}{|c|}{$\begin{array}{l}\text { Factor 5: Support for local community } \\
\text { Eigenvalue = } 1.244 ; \% \text { of Variance }=6.912\end{array}$} & & & .779 & & \\
\hline \multicolumn{3}{|c|}{ To support endeavors of local community } & .862 & .798 & & 0.83 & 18.01 \\
\hline \multicolumn{3}{|c|}{ To support local business and local economy } & .918 & .819 & & 0.73 & 14.95 \\
\hline \multicolumn{3}{|c|}{$\begin{array}{l}\text { Factor 6: Being with people with similar interests } \\
\text { Eigenvalue }=1.009 ; \% \text { of Variance }=5.608\end{array}$} & & & .755 & & \\
\hline \multicolumn{3}{|c|}{ To be with people of similar interest } & .874 & .807 & & 0.80 & 15.65 \\
\hline \multicolumn{3}{|c|}{ To be with people who enjoy the same things I do } & .876 & .807 & & 0.82 & 16.70 \\
\hline Recommended values: & $\mathrm{X}^{2} / \mathrm{df}<3$ & $\mathrm{GFI}>.90$ & $\mathrm{CFI}>.90$ & $\mathrm{NFI}>.90$ & NNFI $>.90$ & RMSEA $<.08$ & SRMR $<.08$ \\
\hline Calculated values: & $X^{2} / d f=1.563$ & $\mathrm{GFI}=.96$ & $\mathrm{CFI}=.99$ & $\mathrm{NFI}=.97$ & $\mathrm{NNFI}=.99$ & RMSEA $=.034$ & SRMR $=.038$ \\
\hline
\end{tabular}

Note: ${ }^{1}$ Cronbach Alpha coefficients are calculated for factors containing at least three items, Spearman-Brown coefficients are presented for two-item dimensions. 


\section{Marketing and Trade}

Tab. 2:

Discriminant validity of the dimensions of motivation

\begin{tabular}{c|c|c|c|c|c|c|c}
$\begin{array}{c}\text { Dimensions } \\
\text { of motivation }\end{array}$ & $\mathbf{1}$ & $\mathbf{2}$ & $\mathbf{3}$ & $\mathbf{4}$ & $\mathbf{5}$ & $\mathbf{6}$ & $\begin{array}{c}\text { Composite } \\
\text { reliability }\end{array}$ \\
\hline 1 & $\mathbf{0 . 4 5 0}$ & & & & & & 0.829 \\
\hline 2 & 0.137 & $\mathbf{0 . 6 3 1}$ & & & & & 0.833 \\
\hline 3 & 0.281 & 0.116 & $\mathbf{0 . 6 1 1}$ & & & & 0.757 \\
\hline 4 & 0.384 & 0.067 & 0.176 & $\mathbf{0 . 6 0 8}$ & & & 0.756 \\
\hline 5 & 0.240 & 0.25 & 0.096 & 0.194 & $\mathbf{0 . 6 1 1}$ & & 0.757 \\
\hline 6 & 0.240 & 0.067 & 0.044 & 0.109 & 0.084 & $\mathbf{0 . 6 5 6}$ & 0.792 \\
\hline
\end{tabular}

Source: own

Note: Values on the diagonal are AVEs, values below the diagonal are squared correlations among the dimensions of motivation; correlations are significant at $p<.01$

\section{Tab. 3: Standardized estimates and $t$-values of second-order CFA}

\begin{tabular}{|c|c|c|c|}
\hline \multicolumn{2}{|l|}{ Parameters } & St. estimates & t-value \\
\hline \multicolumn{2}{|l|}{ Motiv2nd $\rightarrow$ New and different things } & 0.84 & 14.42 \\
\hline \multicolumn{2}{|l|}{ Motiv2nd $\rightarrow$ Reconnection with culture } & 0.51 & 11.43 \\
\hline \multicolumn{2}{|l|}{ Motiv2nd $\rightarrow$ Family togetherness } & 0.62 & 11.87 \\
\hline \multicolumn{2}{|l|}{ Motiv2nd $\rightarrow$ Reducing tension } & 0.66 & 13.35 \\
\hline \multicolumn{2}{|l|}{ Motiv2nd $\rightarrow$ Support for local community } & 0.61 & 13.72 \\
\hline \multicolumn{2}{|c|}{ Motiv2nd $\rightarrow$ Being with people with similar interests } & 0.48 & 8.91 \\
\hline \multirow[t]{6}{*}{ New and different things } & PM12 & 0.63 & - \\
\hline & PM13 & 0.52 & 13.75 \\
\hline & PM15 & 0.65 & 17.03 \\
\hline & PM20 & 0.72 & 16.47 \\
\hline & PM21 & 0.75 & 15.79 \\
\hline & PM22 & 0.64 & 14.54 \\
\hline \multirow[t]{3}{*}{ Reconnection with culture } & PM23 & 0.87 & - \\
\hline & PM24 & 0.90 & 24.22 \\
\hline & PM25 & 0.61 & 15.26 \\
\hline \multirow[t]{2}{*}{ Family togetherness } & PM16 & 0.82 & - \\
\hline & PM17 & 0.77 & 14.24 \\
\hline \multirow[t]{2}{*}{ Reducing tension } & PM26 & 0.76 & - \\
\hline & PM27 & 0.81 & 15.87 \\
\hline \multirow[t]{2}{*}{ Support for local community } & PM29 & 0.82 & - \\
\hline & РM30 & 0.75 & 12.66 \\
\hline \multirow[t]{2}{*}{ Being with people with similar interests } & PM5 & 0.79 & - \\
\hline & PM6 & 0.81 & 10.24 \\
\hline
\end{tabular}


First-order CFA also provided evidence in support of construct validity of dimensions of visitors' motivation. Composite reliabilities of dimensions of motivation higher than 0.60 and statistically significant loadings of indicators on their respective factors, higher than 0.50 , provided evidence in support of convergent validity. As average variance extracted (AVE) of each construct was higher than the square of its correlation with any other construct (Fornell \& Larcker, 1981), discriminant validity was also supported (Tab. 2).

A second order confirmatory factor analysis of visitors' motivation was performed subsequently, on a sample of 770 festival visitors, to examine relationships between visitors' motivation as a higher-order construct and six first-order dimensions of motivation. The measurement model of visitors' motivation as a second-order construct had acceptable model fit indices (Satorra-Bentler $X^{2} / \mathrm{df}=2.46$, $\mathrm{GFI}=0.95, \mathrm{CFI}=0.98, \mathrm{NFI}=0.97, \mathrm{NNFI}=0.98$, RMSEA $=0.044$, SRMR $=0.047$ ) which provided evidence that the model fitted the data well. All gamma coefficients, representing the impact of visitors' motivation as a higher-order construct on the dimensions of motivation were statistically significant and, with the exception of one pattern coefficient in magnitude of 0.48 , other structural coefficients ranged between 0.51 and 0.84 , as shown in Tab. 3 . These findings provided support for the viability of visitors' motivation as a higher-order construct. The second-order factorial structure provided a more parsimonious framework to examine the impact of the fulfilment of motives on visitors' behavioural intentions.

Confirmatory factor analysis was applied to examine construct validity of perceived value, visitors' satisfaction, subjective wellbeing and behavioural intentions. The model was tested on responses from 770 festival visitors. Although the fit of the model was satisfactory, the modification indices suggested adding an error covariance between two items related to visitors' behavioural intentions, which resulted in the decrease in chi-square of 259.7. The model was re-examined and confirmatory factor analysis resulted in acceptable fit indices (Satorra-Bentler $X^{2}$ / $\mathrm{df}=3.41, \mathrm{GFI}=0.94, \mathrm{CFI}=0.99, \mathrm{NFI}=0.98$, $\mathrm{NNFI}=0.99, \mathrm{RMSEA}=0.065, \mathrm{SRMR}=0.035)$.

\section{Tab. 4: Standardized estimates and t-values corresponding to perceived value, satisfaction, well-being, behavioural intentions}

\begin{tabular}{|c|c|c|c|}
\hline Parameters & St. estimates & t-value & Cronbach's alpha \\
\hline Value $\rightarrow$ V1 & 0.74 & 22.42 & \multirow{4}{*}{.875} \\
\hline Value $\rightarrow$ V2 & 0.83 & 27.75 & \\
\hline Value $\rightarrow$ V3 & 0.80 & 25.40 & \\
\hline Value $\rightarrow$ V4 & 0.82 & 27.73 & \\
\hline Satisfaction $\rightarrow$ S1 & 0.84 & 25.97 & \multirow{3}{*}{.895} \\
\hline Satisfaction $\rightarrow$ S2 & 0.87 & 29.14 & \\
\hline Satisfaction $\rightarrow$ S3 & 0.87 & 27.91 & \\
\hline Well-being $\rightarrow$ WB1 & 0.86 & 29.82 & \multirow{3}{*}{.846} \\
\hline Well-being $\rightarrow$ WB2 & 0.82 & 26.38 & \\
\hline Well-being $\rightarrow$ WB3 & 0.74 & 24.89 & \\
\hline Behavioural int. $\rightarrow$ BI1 & 0.67 & 22.31 & \multirow{5}{*}{.861} \\
\hline Behavioural int. $\rightarrow$ BI2 & 0.70 & 23.74 & \\
\hline Behavioural int. $\rightarrow$ BI3 & 0.89 & 29.80 & \\
\hline Behavioural int. $\rightarrow$ BI4 & 0.79 & 25.64 & \\
\hline Behavioural int. $\rightarrow$ BI5 & 0.62 & 18.12 & \\
\hline
\end{tabular}




\begin{tabular}{|c|c|c|c|c|c|}
\hline Tab. 5: & $\begin{array}{l}\text { of the } \\
\text { aviour }\end{array}$ & $\begin{array}{l}\text { ucts percei } \\
\text { ntions }\end{array}$ & value, satis & ion, well-bei & \\
\hline & Value & Satisfaction & Well-being & $\begin{array}{l}\text { Behavioural } \\
\text { intentions }\end{array}$ & $\begin{array}{c}\text { Composite } \\
\text { reliability }\end{array}$ \\
\hline Value & 0.637 & & & & 0.875 \\
\hline Satisfaction & 0.504 & 0.739 & & & 0.773 \\
\hline Well-being & 0.423 & 0.563 & 0.653 & & 0.849 \\
\hline $\begin{array}{l}\text { Behavioural } \\
\text { intentions }\end{array}$ & 0.260 & 0.476 & 0.409 & 0.548 & 0.856 \\
\hline
\end{tabular}

Source: own

Note: Values on the diagonal are AVEs, values below the diagonal are squared correlations among the constructs; correlations are significant at $p<.01$

All regression coefficients between indicators and factors were statistically significant and higher than 0.50 , indicating convergent validity of the constructs. Standardized estimates and corresponding t-values are presented in Tab. 4.

Convergent validity was also supported by composite reliabilities higher than 0.60 . Evidence in support of discriminant validity was provided by AVE values of constructs being higher than the squared correlation between respective and all other constructs, as presented in Tab. 5.

\subsection{Analysis of Structural Relationships}

Structural equation modelling, with robust maximum likelihood as a method of parameter estimation, was applied to examine dependence relationships among the constructs. Satorra-
Bentler normed chi-square $\left(X^{2} / d f=2.32\right)$ together with other fit indices $(\mathrm{GFI}=0.91, \mathrm{CFI}=0.98$, $\mathrm{NFI}=0.97, \mathrm{NNFI}=0.98, \mathrm{RMSEA}=0.041$, SRMR $=0.052$ ) indicated acceptable fit of the model to the data.

Results of hypotheses testing are presented in Tab. 6. In total, seven out of eight hypotheses are supported. Findings of the study indicate that visitors' motivation directly impacts both perceived value of a festival experience $\left(\mathrm{V}_{21}=0.55, \mathrm{t}=12.46\right)$ and visitors' satisfaction $\left(\gamma_{31}=0.18, t=3.62\right)$, providing support for hypotheses $\mathrm{H} 1$ and $\mathrm{H} 2$. Perceived value of a festival experience has significant positive effect on visitors' satisfaction $\left(\beta_{32}=0.62, t=11.13\right)$. Therefore, hypothesis $H 3$ is supported. Although perceived value of a festival experience is not directly related to

\section{Tab. 6: The results of hypothesis testing}

\begin{tabular}{l|c|c|c}
\multicolumn{1}{c|}{ Hypotheses } & St. estimates & t-value & Results \\
\hline H1: Visitors' motivation $\rightarrow$ Perceived value & 0.55 & 12.46 & Supported \\
\hline H2: Visitors' motivation $\rightarrow$ Satisfaction & 0.18 & 3.62 & Supported \\
\hline H3: Perceived value $\rightarrow$ Satisfaction & 0.62 & 11.13 & Supported \\
\hline H4: Perceived value $\rightarrow$ Behavioural intentions & -0.02 & -0.26 & Not supported \\
\hline H5: Satisfaction $\rightarrow$ Behavioural intentions & 0.55 & 6.44 & Supported \\
\hline H6: Perceived value $\rightarrow$ Subjective well-being & 0.25 & 4.48 & Supported \\
\hline H7: Satisfaction $\rightarrow$ Subjective well-being & 0.58 & 10.01 & Supported \\
\hline H8: Well-being $\rightarrow$ Behavioural intentions & 0.24 & 3.35 & Supported \\
\hline
\end{tabular}


visitors' behavioural intentions $\left(\beta_{52}=-0.02\right.$, $\mathrm{t}=-0.26)$, it is an indirect antecedent to visitors' behavioural intentions, through its impact on visitors' satisfaction which directly influences behavioural intentions $\left(\beta_{53}=0.55, \mathrm{t}=6.44\right)$ and its direct impact on visitors' subjective well-being $\left(\beta_{54}=0.25, t=4.48\right)$. These findings therefore provided support for hypotheses $\mathrm{H} 5$ and $H 6$, whereas hypothesis $H 4$ is rejected. As hypothesized, visitors' satisfaction emerged as a direct positive determinant of subjective wellbeing $\left(\beta_{43}=0.58, t=10.01\right)$, thus supporting hypothesis $H 7$. Finally, findings of the study indicate significant positive impact of subjective well-being on visitors' behavioural intentions $\left(\beta_{54}=0.24, t=3.35\right)$. Support has, therefore, been provided for hypothesis $H 8$. More than half of the variance in visitors' behavioural intentions $\left(R^{2}=0.54\right)$ was accounted for by visitors' motivation, perceived value, satisfaction and subjective well-being, indicating good explanatory power of the model. The model also explains $31 \%, 53 \%$ and $60 \%$ of the variance in perceived value, satisfaction and subjective well-being, respectively.

\section{Discussion}

The main objective of this study was to propose and empirically examine a model of the influential factors of festival visitors' future intentions in the context of traditional cultural festivals in Central Europe. Cultural festivals taking place in Slovakia provided the context for this study. This research provided support for the second-order factorial structure of visitors' motivation and identified six motivational domains in the context of traditional cultural festivals in Slovakia, such as experiencing new and different things, reconnection with culture and traditions, family togetherness, reducing tension, supporting local community and being with people with similar interests. Resulting domains of motivation are generally consistent with those emanating from previous research, which suggests that there may be universal drivers of festival attendance. According to the loadings of motivational domains on motivation as a higher-order construct, this study shows that festival attendance is mostly motivated by experiencing something new and different, whereas at a festival venue Slovak visitors are least concerned about being surrounded by people of similar interests. This finding indicates that traditional cultural festivals are appraised by the visitors as a disruption from everyday purposeful life, whereas a variety of other opportunities exists to spend time with people who share similar interests. Therefore, festival organizers are advised to pay due attention to the innovation of festival programme and other aspects of a festival, such as e.g. festival scope, which may shape visitors' perceptions.

Unlike majority of previous studies which examined the importance of motivational domains, this study examined the contribution of the fulfilment of motives on the formation of visitors' value perceptions and satisfaction. According to this study's findings, the fulfilment of motives positively shapes value perceptions and contributes to visitor satisfaction, whereas the direct impact of the fulfilment of motives is more relevant in case of value perceptions. An important contribution of this study lies in the disclosure of the contribution of perceived value of a festival experience and satisfaction with a festival to the formation of visitors' well-being. This finding indicates that local communities which host festivals have a potential to improve residents' and other visitors' quality of life by the delivery of festival experience which would be perceived by attendees as a good value for money, time and energy spent and which exceeds visitors' expectations. Both satisfaction and subjective well-being emerged as direct antecedents to visitors' behavioural intentions, i.e. their willingness to revisit the festival again in the future and recommend festival visitation to their friends, family members, but also to people from other parts of Slovakia to visit the festivals and foreigners to come and visit the festival to get to know better Slovak customs and traditions. This finding implies that the present delivery of satisfactory festival experience not only contributes to visitors' well-being, but it may also contribute to festival's sustainability, by attracting new visitors as a consequence of positive word-of-mouth communication of present visitors. Satisfaction and well-being of visitors also emerged as the mediators of effect of visitors' motivation and perceived value of a festival experience on post-visitation intentions.

In spite of important contributions of the present study to theory and management, it also has a few limitations. The main limitation of the study is related to the scope of its sample. As the present study referred to traditional cultural festivals taking place in 
Slovakia, and responses to the questionnaire items were provided mainly by inhabitants of Central Slovakia, this drawback prevents generalizability of the study's findings to the context of traditional cultural festivals taking place in Central Europe as a whole. Crosssectional design is another limitation of the study, due to which causal relationships should be considered with caution. It should be also noted that field research for the purpose of this study was conducted in winter period and unfavourable weather conditions prevented on-site interviewing of festival visitors. As data collection was performed on locations which were regarded as more convenient for questionnaire fulfilment, such as shopping malls, some other factors, such as ambient conditions at the place of interviewing or respondents' mood at the moment of surveying, might have interfered with respondents' recollection of a recently visited cultural festival. These limitations provide fruitful avenues for future research, which are briefly discussed in the following section.

\section{Conclusions}

In an increasingly competitive festival market, knowledge of what drives attendees' revisit intentions and willingness to recommend a festival is paramount for future success and viability of a festival. This study attempted to shed some light on the determinants of visitors' behavioural intentions in thus far scarcely examined context of traditional cultural festivals in Slovakia. Findings of the study indicate a higher-order structure of the fulfilment of visitors' motives, comprising six first-order dimensions. Visitor satisfaction and well-being as a consequence of festival attendance emerged as the direct determinants of visitors' behavioural intentions and the mediators of the impact of the fulfilment of motives and perceived value of a festival experience on post-visitation intentions. Results of the study bear relevance for both theory and practice.

This study contributes to the literature in several ways. First, by proposing and examining the determinants of visitors' behavioural intentions in thus far largely unstudied context of traditional cultural festivals in Central Europe, the present study adds to the growing body of knowledge in Tourism and Hospitality Management. Second, by indicating significant impact of perceived value and satisfaction on visitors' subjective well-being and its further impact on visitors' behavioural intentions, the present study enhances our understanding of important societal implications of marketing as an exchange process. As indicated by this study's findings, hosting a festival, which is in essence an exchange process between attendees and organizations and individuals operating on a supply-side of a festival, has the potential to enhance societal well-being by delivering valuable experience and satisfying customers' needs.

Consistent with the findings of previous research in the context of festivals (Kim, Kim, \& Goh, 2011; Lee, 2016; Lee et al., 2008; Yoon, Lee, \& Lee, 2010) the present study has indicated significant direct effect of visitors' satisfaction on behavioural intentions. From a managerial perspective, this finding emphasizes the importance of exceeding visitors' expectations as a prerequisite of future success of a festival. Therefore, in order to enhance visitors' satisfaction and stimulate favourable behavioural intentions, festival organizers are advised to more thoroughly examine visitors' expectations regarding the elements of festival programme and festival scope which would facilitate the fulfilment of visitors' needs and contribute to their perceptions of festival experience as a good value for time, money and effort spent during the festival attendance. Contrary to previous research findings which indicated perceived value as the most important determinant of visitors' behavioural intention (Lee, Yoon, \& Lee, 2007), findings of this study have not provided support for the direct effect of perceived value on visitors' behavioural intentions. A possible explanation for this finding is that nowadays Slovak residents have at their disposal a variety of options to have a quality leisure time and perception of a leisure activity as a good value, in terms of time, effort and money spent, does not necessarily imply a person's willingness to participate in that activity in the future. However, leisure activity such as festival attendance which is perceived as time well-spent and as a satisfactory experience enhances visitors' subjective well-being and further contributes to visitors' intentions to revisit the festival and recommend it to their friends and relatives and according to the findings of this study to recommend the festival to people from other parts of Slovakia and also to foreigners, as an 
opportunity to get to know better Slovak culture and traditions. Accordingly, careful planning and organization of a festival may have positive impact not only on a future success of a festival, but through the enhancement of visitors' satisfaction and well-being may lead to the promotion of internal tourism. In contemporary era of diverse electronic communication, the enhancement of visitors' satisfaction might also affect inbound tourism, by spreading positive word-of-mouth via social media websites, which have been gaining prominence in influencing consumer behaviour (Dabija et al., 2018). Moreover, by incorporating referrals of satisfied festival visitors into their social media material, local and national tourism organizations may employ traditional cultural festivals to promote a hosting community as a tourism destination (Hruška \& Pásková, 2018). In light of present findings and Sirgy's (2010) research indicating that small but frequent doses of positive leisure experience have greater effect on a person's subjective well-being than more intensive, but less frequent doses of reward, local communities are advised to support hosting festivals and similar events which would contribute to the well-being of residents. In contemporary era of social networking, positive word-of-mouth may easily reach wide audience and by attracting new visitors bring about a number of positive socio-economic consequences for a host community.

Limitations of this study open new avenues for research. Harsh weather conditions during the period of data collection for the purpose of this study prevented on-site interviewing of festival visitors. Consequently, responses to the questionnaire items might have been influenced by some other factors to which respondents were exposed during data collection and which were not related to the event which was the subject of evaluation. To overcome this limitation the study should be replicated in different seasons and at festival venues. In regard to the representativeness of the inferences, future studies would benefit from probabilistic sampling techniques. As this study employed a cross-sectional research design, stronger evidence of causality should be provided in future studies by employing longitudinal research design. In view of Oliver's (1999) phases of loyalty, we acknowledge the limitation of relying on visitors' conative, instead of action loyalty. Extension of this study to include both phases of loyalty and the examination of the causal relationship between visitors' behavioural intentions and actual behaviour, employing a longitudinal research design, would be an area worthy of future research. In light of modest amount of variance explained in the construct of perceived value $\left(R^{2}=31 \%\right)$, future researchers are advised to consider additional antecedents of the construct and take into consideration a multidimensional perspective of perceived value. Correspondingly, more integrative framework of the formation of visitors' behavioural intentions would be an avenue worthy of future examination.

Acknowledgements: The authors gratefully acknowledge scholarships for research stay in Slovakia granted by the Slovak Academic Information Agency and the Ministry of Education, Science, Research and Sport of the Slovak Republic, which facilitated collaboration on this study. Work on this study has also been supported by the Ministry of Education, Science and Technological Development of the Republic of Serbia, Project No. 179001.a.

\section{References}

Akhoondnejad, A. (2016). Tourist loyalty to a local cultural event: The case of Turkmen handicrafts festival. Tourism Management, 52, 468-477. https://doi.org/10.1016/j. tourman.2015.06.027

Anderson, J. C., \& Gerbing, D. W. (1988). Structural equation modeling in practice: A review and recommended two-step approach. Psychological Bulletin, 103(3), 411-423. https://doi.org/10.1037/0033-2909.103.3.411

Chen, Y., Lehto, X. Y., \& Cai, L. (2013). Vacation and well-being: A study of Chinese tourists. Annals of Tourism Research, 42, 284-310. https://doi.org/10.1016/j. annals.2013.02.003

Crompton, J. L., \& McKay, S. L. (1997). Motives of Visitors Attending Festival Events. Annals of Tourism Research, 24(2), 425-439. https://doi.org/10.1016/S0160-7383(97)80010-2

Dabija, D., Bejan, B. M., \& Tipi, N. (2018). Generation $X$ versus Millennials communication behaviour on social media when purchasing food versus tourist services. E\&M Economics and Management, 21(1), 191-205. https://dx.doi.org/10.15240/tul/001/2018-1-013 
Dedeoglu, B. B., Bilgihan, A., Ye, B. H., Buonincontri, P., \& Okumus, F. (2018). The impact of servicescape on hedonic value and behavioral intentions: The importance of previous experience. International Journal of Hospitality Management, 72, 10-20. https://doi. org/10.1016/j.ijhm.2017.12.007

Fornell, C., \& Larcker, D. F. (1981). Evaluating Structural Equation Models with Unobservable Variables and Measurement Error. Journal of Marketing Research, 18(1), 39-50. https://doi.org/10.2307/3151312

Getz, D., \& Page, S. J. (2016). Progress and prospects for event tourism research. Tourism Management, 52, 593-631. https://doi. org/10.1016/j.tourman.2015.03.007

Gnoth, J. (1997). Tourism motivation and expectation formation. Annals of Tourism Research, 24(2), 283-304. https://doi. org/10.1016/S0160-7383(97)80002-3

Hair, J. F., Anderson, R. E., Tatham, R. L., \& Black, W. C. (2010). Multivariate Data Analysis: A Global Perspective (7th ed.). Upper Saddle River, NJ: Pearson Prentice Hall.

Han, H., \& Hyun, S. S. (2018). Role of motivations for luxury cruise traveling, satisfaction, and involvement in building traveler loyalty. International Journal of Hospitality Management, 70, 75-84. https://doi. org/10.1016/j.jijm.2017.10.024

Hruška, J., \& Pásková, M. (2018). How do the national tourism organizations use the social media? E\&M Economics and Management, 21(4), 226-240. https://dx.doi. org/10.15240/tul/001/2018-4-015

Hudson, S., Roth, M. S., Madden, T. J., \& Hudson, R. (2015). The effects of social media on emotions, brand relationship quality, and word of mouth: An empirical study of music festival attendees. Tourism Management, 47, 68-76. https://doi.org/10.1016/j.tourman.2014.09.001

Jo, W., Lee, C. K., \& Reisinger, Y. (2014). Behavioral intentions of international visitors to the Korean hanok guest houses: Quality, value and satisfaction. Annals of Tourism Research, 47, 83-86. https://doi.org/10.1016/j. annals.2014.05.003

Kang, S., Kim, K., Ryan, C., \& Park, S. (2014). What Makes People Travel to Cultural Heritage Festival? International Journal of Tourism Sciences, 14(3), 70-88. https://doi.org/ 10.1080/15980634.2014.11434700

Kim, H., Woo, E., \& Uysal, M. (2015). Tourism experience and quality of life among elderly tourists. Tourism Management, 46, 465-476. https://doi.org/10.1016/j.tourman.2014.08.002

Kim, H., Borges, M. C., \& Chon, J. (2006). Impacts of environmental values on tourism motivation: The case of FICA, Brazil. Tourism Management, 27(5), 957-967. https://doi. org/10.1016/j.tourman.2005.09.007

Kim, Y. H., Kim, M. C., \& Goh, B. K. (2011). An examination of food tourist's behavior: Using the modified theory of reasoned action. Tourism Management, 32(5), 1159-1165. https://doi. org/10.1016/j.tourman.2010.10.006

Kim, Y. G., Suh, B. W., \& Eves, A. (2010). The relationships between food-related personality traits, satisfaction, and loyalty among visitors attending food events and festivals. International Journal of Hospitality Management, 29(2), 216-226. https://doi. org/10.1016/j.ijhm.2009.10.015

Lee, C.-K. (2000). A comparative study of Caucasian and Asian visitors to a Cultural Expo in an Asian setting. Tourism Management, 21(2), 169-176. https://doi.org/10.1016/S02615177(99)00046-1

Lee, C.-K., Yoon, Y.-S., \& Lee, S.-K. (2007). Investigating the relationships among perceived value, satisfaction, and recommendations: The case of the Korean DMZ. Tourism Management, 28(1), 204-214. https://doi.org/10.1016/j. tourman.2005.12.017

Lee, T. H., \& Hsu, F. Y. (2013). Examining How Attending Motivation and Satisfaction Affects the Loyalty for Attendees at Aboriginal Festivals. International Journal of Tourism Research, 15(1), 18-34. https://doi. org/10.1002/jtr.867

Lee, J.-S., Lee, C.-K., \& Yoon, Y. (2009). Investigating differences in antecedents to value between first-time and repeat festival-goers. Journal of Travel and Tourism Marketing, 26(7), 688-702. https://doi. org/10.1080/10548400903284511

Lee, J., \& Beeler, C. (2009). An investigation of predictors of satisfaction and future intention: links to motivation, involvement, and service quality in a local festival. Event Management, 13(1), 17-29. https://doi. org/10.3727/152599509789130584

Lee, Y.-K. (2016). Impact of government policy and environment quality on visitor loyalty to Taiwan music festivals: Moderating effects of revisit reason and occupation type. Tourism Management, 53, 187-196. https://doi. org/10.1016/j.tourman.2015.10.004 
Lee, Y.-K., Lee, C.-K., Lee, S.-K., \& Babin, B. J. (2008). Festivalscapes and patrons' emotions, satisfaction, and loyalty. Journal of Business Research, 61(1), 56-64. https://doi. org/10.1016/j.jbusres.2006.05.009

Lo, A. S., \& Lee, C. Y. S. (2011). Motivations and perceived value of volunteer tourists from Hong Kong. Tourism Management, 32(2), 326-334. https://doi.org/10.1016/j. tourman.2010.03.002

Maráková, V., Dyr, T., \& Wolak-Tuzimek, A. (2016). Factors of tourism's competitiveness in the European union countries. E\&M Economics and Management, 19(3), 92-109. http://dx.doi. org/10.15240/tul/001/2016-3-007

Mason, M. C., \& Paggiaro, A. (2012). Investigating the role of festivalscape in culinary tourism: The case of food and wine events. Tourism Management, 33(6), 1329-1336. https://doi.org/10.1016/j.tourman.2011.12.016

Meng, B., \& Choi, K. (2017). Theme restaurants' servicescape in developing quality of life: The moderating effect of perceived authenticity. International Journal of Hospitality Management, 65, 89-99. https://doi. org/10.1016/j.jhm.2017.06.011

Mohr, K., Backman, K. F., Gahan, L. W., \& Backman, S. J. (1993). An Investigation of Festival Motivations and Event Satisfaction by Visitor Type. Festival Management and Event Tourism, 1(3), 89-97. https://doi. org/10.3727/106527093792337619

Newbold, C., Jordan, J., Bianchini, F., \& Maughan, C. (2015). Focus on festivals: Contemporary European case studies and perspectives. Oxford: Goodfellow Publishers Ltd.

Nicholson, R. E., \& Pearce, D. G. (2001). Why Do People Attend Events: A Comparative Analysis of Visitor Motivations at Four South Island Events. Journal of Travel Research, 39(4), 449-460. https://doi. org/10.1177/004728750103900412

Oliver, R. (1999). Whence Consumer Loyalty? Journal of Marketing, 63(Special Issue), 33-44. https://doi.org/10.2307/1252099

Park, K.-S., Reisinger, Y., \& Kang, H.J. (2008). Visitors' motivation for attending the South Beach Wine and Food Festival, Miami Beach, Florida. Journal of Travel and Tourism Marketing, 25(2), 161-181. https://doi. org/10.1080/10548400802402883

Prebensen, N. K., \& Xie, J. (2017). Efficacy of co-creation and mastering on perceived value and satisfaction in tourists' consumption.
Tourism Management, 60, 166-176. https://doi. org/10.1016/j.tourman.2016.12.001

Prebensen, N. K., Woo, E., \& Uysal, M. S. (2014). Experience value: antecedents and consequences. Current Issues in Tourism, 17(10), 910-928. https://doi.org/10.1080/1368 3500.2013.770451

Pyke, S., Hartwell, H., Blake, A., \& Hemingway, A. (2016). Exploring well-being as a tourism product resource. Tourism Management, 55, 94-105. https://doi. org/10.1016/j.tourman.2016.02.004

Reichheld, F. F. (2003). The One Number You Need to Grow. Harvard Business Review, 81(12), 46-54.

Schofield, P., \& Thompson, K. (2007). Visitor motivation, satisfaction and behavioural intention: the 2005 Naadam Festival, Ulaanbaatar. International Journal of Tourism Research, 9(5), 329-344. https://doi. org/10.1002/jtr.638

Sirgy, M. J. (2010). Toward a Quality-of-Life Theory of Leisure Travel Satisfaction. Journal of Travel Research, 49(June 2009), 246-260. https://doi.org/10.1177/0047287509337416

Slovakia Travel. (2017). Slovak folklore is extraordinary. Retrieved August 1, 2017 from http://slovakia.travel/en/things-to-see-and-do/ traditions-and-gastronomy/folklore-events

Su, L., Swanson, S. R., \& Chen, X. (2016). The effects of perceived service quality on repurchase intentions and subjective wellbeing of Chinese tourists: The mediating role of relationship quality. Tourism Management, 52, 82-95. https://doi.org/10.1016/j. tourman.2015.06.012

Sung, Y. K., Su, C. S., \& Chang, W. C. (2016). The quality and value of Hualien's Amis Harvest Festival. Annals of Tourism Research, 56, 128-131. https://doi.org/10.1016/j. annals.2015.10.001

Tabachnick, G. B., \& Fidell, S. L. (2007). Using Multivariate Statistics (5th ed.). Boston, MA: Pearson Education Inc.

Tkaczynski, A., \& Rundle-Thiele, S. R. (2011). Event segmentation: A review and research agenda. Tourism Management, 32(2), 426-434. https://doi.org/10.1016/j. tourman.2010.03.010

Uysal, M., Sirgy, M. J., Woo, E., \& Kim, H. (L.). (2016). Quality of life (QOL) and well-being research in tourism. Tourism Management, 53, 244-261. https://doi.org/10.1016/j. tourman.2015.07.013 
Wu, H.-C., Wong, J. W.-C., \& Cheng, C.C. (2014). An Empirical Study of Behavioral Intentions in the Food Festival: The Case of Macau. Asia Pacific Journal of Tourism Research, 19(11), 1278-1305. https://doi.org/1 $0.1080 / 10941665.2013 .844182$

Yolal, M., Gursoy, D., Uysal, M., Kim, H. (L.), \& Karacaoğlu, S. (2016). Impacts of festivals and events on residents' wellbeing. Annals of Tourism Research, 61, 1-18. https://doi.org/10.1016/j.annals.2016.07.008
Yoon, Y.-S., Lee, J.-S., \& Lee, C.-K. (2010). Measuring festival quality and value affecting visitors' satisfaction and loyalty using a structural approach. International Journal of Hospitality Management, 29(2), 335-342. https://doi.org/10.1016/j.ijhm.2009.10.002

Note: Covariance matrix, used as an input for SEM, can be obtained from the first author, upon request. 


\section{Appendix A: Questionnaire items with descriptive statistics - Part 1}

\begin{tabular}{|c|c|c|c|c|c|}
\hline & Constructs and items & Mean & $\begin{array}{c}\text { St. } \\
\text { deviation }\end{array}$ & $\begin{array}{l}\text { Skew- } \\
\text { ness }\end{array}$ & Kurtosis \\
\hline \multicolumn{6}{|c|}{ New and different things } \\
\hline PM12 & $\begin{array}{l}\text { Visiting festival provided an opportunity } \\
\text { to experience something new }\end{array}$ & 4.64 & 1.532 & -0.371 & -0.430 \\
\hline PM13 & $\begin{array}{l}\text { Visiting festival provided an opportunity } \\
\text { to satisfy curiosity }\end{array}$ & 4.12 & 1.712 & -0.133 & -0.826 \\
\hline PM15 & $\begin{array}{l}\text { Visiting festival provided an opportunity to } \\
\text { experience something stimulating and exciting }\end{array}$ & 4.33 & 1.547 & -0.302 & -0.550 \\
\hline PM20 & $\begin{array}{l}\text { Festival provided a variety of things to see and } \\
\text { do }\end{array}$ & 4.11 & 1.499 & -0.145 & -0.534 \\
\hline PM21 & $\begin{array}{l}\text { Festival provided an opportunity to experience } \\
\text { something different }\end{array}$ & 4.21 & 1.517 & -0.149 & -0.427 \\
\hline PM22 & $\begin{array}{l}\text { Festival provided an opportunity to experience } \\
\text { a unique event }\end{array}$ & 4.75 & 1.570 & -0.474 & -0.402 \\
\hline \multicolumn{6}{|c|}{ Reconnection with culture and traditions } \\
\hline PM23 & $\begin{array}{l}\text { Festival provided an opportunity to reconnect } \\
\text { with local customs and tradition }\end{array}$ & 4.99 & 1.623 & -0.604 & -0.368 \\
\hline PM24 & $\begin{array}{l}\text { Festival provided an opportunity to reconnect } \\
\text { with local culture }\end{array}$ & 4.76 & 1.638 & -0.443 & -0.599 \\
\hline PM25 & $\begin{array}{l}\text { Festival provided an opportunity to enjoy } \\
\text { traditional food and handicrafts }\end{array}$ & 5.53 & 1.447 & -0.983 & 0.482 \\
\hline \multicolumn{6}{|c|}{ Family togetherness } \\
\hline PM16 & $\begin{array}{l}\text { Festival provided an opportunity for the entire } \\
\text { family to enjoy }\end{array}$ & 5.48 & 1.368 & -0.911 & 0.528 \\
\hline PM17 & $\begin{array}{l}\text { Festival provided an opportunity for all family } \\
\text { members to do something together }\end{array}$ & 5.55 & 1.474 & -1.053 & 0.595 \\
\hline \multicolumn{6}{|c|}{ Reducing tension } \\
\hline PM26 & $\begin{array}{l}\text { Festival provided an opportunity to reduce } \\
\text { built-up tension, anxieties and frustrations }\end{array}$ & 4.39 & 1.663 & -0.272 & -0.651 \\
\hline PM27 & $\begin{array}{l}\text { Festival provided an opportunity to recover from } \\
\text { my usually hectic life }\end{array}$ & 4.14 & 1.731 & -0.138 & -0.831 \\
\hline \multicolumn{6}{|c|}{ Support for local community } \\
\hline PM29 & $\begin{array}{l}\text { Festival provided an opportunity to support } \\
\text { endeavours of local community }\end{array}$ & 4.22 & 1.822 & -0.191 & -0.918 \\
\hline PM30 & $\begin{array}{l}\text { Festival provided an opportunity to support local } \\
\text { business and local economy }\end{array}$ & 4.59 & 1.752 & -0.370 & -0.758 \\
\hline \multicolumn{6}{|c|}{ Being with people with similar interests } \\
\hline PM5 & $\begin{array}{l}\text { Festival provided an opportunity to be with } \\
\text { people of similar interest }\end{array}$ & 4.41 & 1.647 & -0.312 & -0.714 \\
\hline PM6 & $\begin{array}{l}\text { Festival provided an opportunity to be with } \\
\text { people who enjoy the same things I do }\end{array}$ & 4.19 & 1.582 & -0.212 & -0.603 \\
\hline \multicolumn{6}{|c|}{ Perceived value of a festival experience } \\
\hline $\mathrm{V} 1$ & $\begin{array}{l}\text { Compared to the price I paid, I think I have } \\
\text { received good value }\end{array}$ & 4.25 & 1.444 & -0.207 & -0.411 \\
\hline
\end{tabular}




\section{Appendix A: Questionnaire items with descriptive statistics - Part 2}

\begin{tabular}{|c|c|c|c|c|c|}
\hline & Constructs and items & Mean & \begin{tabular}{c|} 
St. \\
deviation
\end{tabular} & $\begin{array}{c}\text { Skew- } \\
\text { ness }\end{array}$ & Kurtosis \\
\hline V2 & $\begin{array}{l}\text { Compared to the effort I spent, I think I have } \\
\text { received good value }\end{array}$ & 4.43 & 1.444 & -0.311 & -0.346 \\
\hline V3 & $\begin{array}{l}\text { Compared to the time I spent, I think I have } \\
\text { received good value }\end{array}$ & 4.75 & 1.420 & -0.486 & -0.083 \\
\hline V4 & $\begin{array}{l}\text { Overall, I think my experience was a good value } \\
\text { for money, time and effort I spent }\end{array}$ & 4.59 & 1.383 & -0.358 & -0.200 \\
\hline \multicolumn{6}{|c|}{ Visitors' satisfaction } \\
\hline S1 & This festival has exceeded my expectations & 5.17 & 1.274 & -0.601 & 0.306 \\
\hline $\mathrm{S} 2$ & $\begin{array}{l}\text { I believe I made the right choice in attending this } \\
\text { festival }\end{array}$ & 4.85 & 1.355 & -0.431 & -0.060 \\
\hline S3 & I am very satisfied with this festival & 5.20 & 1.318 & -0.646 & 0.247 \\
\hline \multicolumn{6}{|c|}{ Subjective well-being } \\
\hline WB1 & $\begin{array}{l}\text { Overall, I feel this festival has enriched my life. } \\
\text { I am really glad that I visited this festival }\end{array}$ & 4.19 & 1.410 & -0.254 & -0.290 \\
\hline WB2 & $\begin{array}{l}\text { In this festival, I accomplished my purpose of } \\
\text { the experience and this experience has enriched } \\
\text { me in some ways }\end{array}$ & 4.26 & 1.431 & -0.304 & -0.348 \\
\hline WB3 & $\begin{array}{l}\text { This festival was rewarding to me in many ways } \\
\text { that I feel much better about things and myself } \\
\text { with this festival }\end{array}$ & 3.66 & 1.537 & -0.029 & -0.629 \\
\hline \multicolumn{6}{|c|}{ Behavioural intentions } \\
\hline $\mathrm{BI} 1$ & $\begin{array}{l}\text { I would like to attend this festival again in the } \\
\text { future }\end{array}$ & 4.59 & 1.873 & -0.345 & -0.916 \\
\hline $\mathrm{BI} 2$ & $\begin{array}{l}\text { This festival would be my first choice of similar } \\
\text { events in the future }\end{array}$ & 4.48 & 1.713 & -0.354 & -0.654 \\
\hline $\mathrm{BI} 3$ & $\begin{array}{l}\text { I would recommend my friends and relatives } \\
\text { to visit this festival }\end{array}$ & 5.24 & 1.416 & -0.748 & 0.222 \\
\hline $\mathrm{BI} 4$ & $\begin{array}{l}\text { I would recommend other people from Slovakia } \\
\text { to visit this festival }\end{array}$ & 4.99 & 1.558 & -0.648 & -0.211 \\
\hline $\mathrm{BI} 5$ & $\begin{array}{l}\text { I would recommend foreigners to visit this } \\
\text { festival, to get to know better Slovak culture and } \\
\text { traditions }\end{array}$ & 5.15 & 1.658 & -0.773 & -0.155 \\
\hline
\end{tabular}

